\title{
METASTATIC MYOCARDIAL CALCIFICATION
}

\author{
F. BYLSMA AND J.B.W. WALMSLEY
}

\begin{abstract}
A case of metastatic myocardial calcification is reported in a patient with chronic renal failure. The characteristic features are failure to take phosphate-binding antacids on a regular basis, intractable congestive heart failure, atrioventricular block, a calcium phosphate product consistently greater than 60 , and sudden irreversible cardiac arrest. Arteriovenous fistulae created for haemodialysis appear to be an unlikely cause of cardiac failure.
\end{abstract}

KEY WORDS: HEART, myocardial calcification.

Patients With chronic renal failure pose special problems for the anaesthetist. These problems are now well documented. However, metastatic calcific cardiomyopathy, an uncommon complication, has not been emphasized. Since it presents as intractable cardiac failure, atrioventricular block or cardiac arrest, it is important for the anaesthetist to be aware of this entity, and to be able to recognize it preoperatively.

\section{CASE History}

An 11-year-old girl with chronic renal failure, due to reflux nephropathy and chronic pyelonephritis, had been on peritoneal dialysis for 14 months. Nine months before this admission uncontrollable hypertension had necessitated bilateral nephrectomy, and three months later an arteriovenous fistula was created in preparation for haemodialysis. Following nephrectomy her blood pressure, controlled with methyldopa $125 \mathrm{mg}$ daily, varied between $100 / 60$ and $145 / 100 \mathrm{mmHg}$. Blood urea nitrogen (BUN) levels ranged between 16 and $62 \mathrm{mg} / \mathrm{dl}$, serum creatinine between 5.7 and $12.9 \mathrm{mg} / \mathrm{dt}$, haemoglobin from 4.8 to $9.0 \mathrm{gm} / \mathrm{dl}$. Electrolytes were maintained within normal limits. Her general condition, however, deteriorated, with feeding problems, frequent refusal to take phosphatebinding antacids, consequent hyperphosphataemia and a prolonged bout of pneumonitis. During these nine months serum calcium varied between 6.1 and $10.3 \mathrm{mg} / \mathrm{dl}$ and serum phosphate between 4.2 and $14 \mathrm{mg} / \mathrm{dl}$. For the last three

F. Bylsma, M.D., and J.B.W. Walmsley, M.B., F.R.C.P.(C), Department of Anaesthesia, Vancouver General Hospital, Vancouver, B.C. months she had been in congestive cardiac failure; this improved by reducing her post-dialysis 'dry' weight, but never cleared. Occlusion of the arteriovenous fistula resulted in a drop in heart rate from 106 to 92 per minute, but echocardiographically there was no accompanying change in left atrial or ventricular size. When treatment of the heart failure with rigid fluid control and dialysis proved inadequate, it was decided to reduce the flow through the fistula surgically, although it was unclear whether or not it was contributing significantly to the congestive failure state.

Preoperatively she was dialysed and her weight was reduced from 22.7 to $19 \mathrm{~kg}$. Dyspnoea improved, but fine rales persisted over both lung fields. Other findings were: blood pressure $110 / 80 \mathrm{mmHg}$; pulse rate $102 / \mathrm{min}$.; haemoglobin $7.8 \mathrm{gm} / \mathrm{dl}$; serum potassium $3.9 \mathrm{mmol} / 1$.; BUN $18 \mathrm{mg} / \mathrm{dl}$; serum creatinine $5.9 \mathrm{mg} / \mathrm{dl}$; serum calcium $9.9 \mathrm{mg} / \mathrm{dl}$; serum phosphate $10.4 \mathrm{mg} / \mathrm{dl}$. The electrocardiogram showed regular sinus rhythm; rate 104/min; PR interval $0.14 \mathrm{sec}$; left ventricular hypertrophy. Chest $\mathrm{X}$-ray revealed the heart to be moderately increased in size with left ventricular configuration.

Following premedication with meperidine $35 \mathrm{mg}$ and atropine $0.3 \mathrm{mg}$ anaesthesia was induced with thiopentone $50 \mathrm{mg}$ followed by halothane 0.5 per cent in nitrous oxide-oxygen 3:3, with spontaneous/assisted ventilation. Three minutes later her heart rate fell from 100 to $40 / \mathrm{min}$, failed to respond to atropine or isoprenaline and arrested. All resuscitative efforts failed.

At autopsy there was diffuse visceral and nonvisceral calcification. The heart was greatly enlarged with marked left ventricular hypertrophy. 
Miscroscopically there was extensive vascular calcification with calcification of the sarcoplasm and sarcolemnal sheaths in a perivascular pattern; the muscle bundles associated with this calcification were atrophied with increased amounts of collagen. The myocardial cells were hypertrophied, but showed no mineralization. Blood vessels throughout the body were calcified. Prominent atherosclerotic changes were present in the aorta.

\section{Discussion}

This patient presented with cardiac failure. Fluid overload and hypertension are the common causes of congestive heart failure in dialysis patients. However, she failed to respond to aggressive dialysis and antihypertensive therapy, and other causes of failure were considered. These included atherosclerotic heart disease, uraemic pericarditis and endocarditis, together with anaemia and a number of electrolyte disturbances, such as hyperkalaemia, hypocalcaemia, hypermagnesaemia and metabolic acidosis, all of which have been known to exacerbate preexisting heart disease. Unlike naturally occurring arteriovenous fistulae, which may cause high output cardiac failure, it seems unlikely that the arteriovenous shunts and fistulae created to facilitate haemodialysis will, by themselves, produce heart failure or significant cardiomegaly. So concluded Johnson, et al.,' who followed the cardiovascular status of patients with such shunts for three years. They found that a hyperdynamic state with increased heart rate and cardiac output occurred shortly after the creation of the shunt, but subsequently there was no further increase in cardiac output, or measurable evidence of left ventricular strain. Gotloib ${ }^{2}$ and Hildebrand ${ }^{3}$ each reported a patient with high output failure who failed to show any improvement after closure of a fistula. When all these causes of failure have been excluded, a diagnosis of uraemic cardiomyopathy, ${ }^{4}$ secondary to a cardiotoxin as yet unidentified, has been postulated by some; it may occur in 2-4 per cent of chronic dialysis patients.

An uncommon complication of chronic renal failure that may cause congestive heart failure is calcific cardiomyopathy. ${ }^{5-7}$ Stanbury ${ }^{8}$ showed that a calcium $\times$ phosphate product exceeding 75 indicates plasma saturation and favours metastatic soft tissue calcification. High serum phosphate levels are a consequence of the imbalance between oral intake of phosphate, unmodified intestinal absorption, and impaired renal excretion, which accompany renal failure. Hyperphosphataemia increases bone deposition of phosphate and calcium and produces hypocalcaemia. Secondary hyperparathyroidism or vitamin D therapy may subsequently result in normal or elevated calcium levels. In these patients metastatic soft tissue calcification can occur. Lowering of serum phosphate levels may result from dialysis, from restriction of food with high phosphate contents and, perhaps most importantly, from the use of phosphate-binding antacids which limit alimentary absorption. Metastatic calcification may be visceral, involving heart, lungs and kidneys, and it may be nonvisceral, affecting subcutaneous tissues, skin, eyes and blood vessels. Of functional importance in the heart is calcium deposition in the AV node, interventricular septum and left ventricular myocardium, where it is responsible for heart block and left ventricular failure. ${ }^{9}$ Clinical features of calcific cardiomyopathy include congestive failure unresponsive to fluid restriction and atrioventricular block. When these findings occur in the presence of a high calcium $\times$ phosphate product, this diagnosis should be considered. Visceral calcification is not seen on X-ray. Evidence of non-visceral calcification, seen both clinically as calcium deposits in the eye or periarticularly, or radiologically intra- or periarticularly, or as calcified major vessels, may suggest visceral calcification. Although nonvisceral calcification will resolve by controlling serum phosphate levels or following parathyroidectomy, visceral calcification does not appear to be reversible.

During the induction of anaesthesia with halothane bradycardia developed and progressed to cardiac asystole and death. In the absence of significant electrolyte abnormalities, and with adequate ventilation and oxygenation, this event is attributed to calcification of the myocardium and the conducting system. Halothane is known to cause depression of the sinus node; and bradycardia and junctional rhythm are commonly seen with this agent. The possibility that halothane may have contributed to the bradycardia cannot be excluded. However, the occurrence of this arrhythmia early in the anaesthetic, the low concentration of halothane, the lack of response to atropine and the rapid progression to asystole, are more consistent with the underlying cardiomyopathy than with a halothane-induced arrhythmia. 


\section{ACKNOWLEDGEMENT}

We would like to thank Dr. D.S. Lirenman, M.D., F.R.C.P.(C) for his help in the preparation of this report.

\section{REFERENCES}

1. Johnson, G., JR. \& BLythe, W.B. Haemodynamic Effects of Arteriovenous Shunts Used For Haemodialysis. Ann. Surg. 17I: 715-723 (1970).

2. Gotloib, L. \& Servadio, A. A Possible Case of Beriberi Heart Failure In A Chronic Haemodialysis Patient. Nephron. 14: 293-298 (1975).

3. Hildegrand, H.D. Personal communication.

4. Drueke, T., le Pailleur, C., Meilhac, B. Coutoudis, C., Zingraff, J., Jungers, P., Di Matteo, J. \& Crosnier, J. Congestive Cardiomyopathy In Uremia; Hemodynamic and An- giographic Studies. Kidney International //(4) 289-290 (1977).

5. Henderson, R.R., Santiago, L.M., Spring, D.A. \& HARRINGTON, A.R. Metastatic Myocardial Calcification In Chronic Renal Failure Presenting As Atrioventricular Block. New Eng. J. Med. 284: $1252-1253$ (1971).

6. Koshy, M.C. \& Weinstein, E. Calcific Cardiomyopathy. New Eng. J. Med. Correspondence. 292: 209 (1975).

7. Arora, K.K., Lacy, J.P., Schact, R.A., MarTIN, D.G. \& GUTCH, F. Calcific Cardiomyopathy In Advanced Renal Failure. Arch. Intern. Med. 135: 603-605 (1975).

8. Stanbury, S.W. \& Lamb, G.A. Parathyroid Function In Chronic Renal Failure. Quart. J. Med. 137: 1-23 (1966).

9. Terman, D.S., Alfrey, A.C. \& Hammond, W.S. Cardiac Calcification in Uraemia: A Clinical, Biochemical And Pathological Study. Am. J. Med. 50: 744-755 (1971).

\section{RÉSUMÉ}

Les auteurs rapportent un cas de cardiomyopathie avec calcifications métastatiques chez une patiente en insuffisance rénale chronique. On constate dans ces cas que les patients n'ont pas pris régulièrement d'antacides permettant de fixer les phosphates, qu'ils présentent une insuffisance cardiaque congestive rebelle, un bloc auriculoventriculaire, un produit calciumphosphate plus grand que 60 de façon persistante et une évolution vers un arrêt cardiaque irréversible. Les fistules artério-veineuses utilisées pour fins d'hémodialyse ne semblent pas la cause de l'insuffisance cardiaque congestive. 